\title{
Survey of Intracellular Protein Extraction Methods from Pichia pastoris
}

\author{
Yuli Wang, Yuansen Hu, Yang Lei, Yangyong Lv, Le Wang, Hongwei Wei \\ Bioengineering College, Henan University of Technology, Zhengzhou, China \\ Email:292831280@qq.com
}

Received 21 November 2015; accepted 10 December 2015; published 17 December 2015

\begin{abstract}
The broken efficiency of cell wall and the release amount of Pichia pastoris intracellular protein under different cell breaking conditions were investigated in this paper. The results showed that broken efficiency using hot alkali combined with high-pressure homogenizing method was higher than that of enzyme hydrolysis, hot alkali treatment and high-pressure homogenation, respectively. Suspended medium had little effect on the broken efficiency of yeast cell, but had significant effect on the protein release yield. The results indicated that optimal condition for intracellular proteins extraction was $30 \%$ (wet weight, w/v) of yeast cells suspend in $50 \mathrm{mM}$ phosphate buffer (pH 10.0), water bathed at $60^{\circ} \mathrm{C}$ for 2 hours, homogenized twice at $100 \mathrm{MPa}$ pressure. The broken efficiency of Pichia pastoris cell could reach $87.6 \%$ and the protein yield was $35.48 \mathrm{~g}$ per $100 \mathrm{~g}$ cells.
\end{abstract}

\section{Keywords}

Pichia pastoris, High Temperature and Alkali Treatment, High Pressure Homogeniza-Tion, Cell Wall Breaking, Protein Extraction

\section{Introduction}

The methylotrophic yeast Pichia pastoris has become one of the most widely used expression systems for recombinant protein production (Jia-kun Dai et al., 2012) [1]. More than 500 kinds of proteins have been successfully expressed since the beginning of 1980s. Part of the products has been successfully used in aquatic breed, feeding processing and other industries (Rui-juan Lou et al., 2010) [2]. With the increasing application of this genetic engineering yeast in fermentation industry, a large number of waste yeast residual is produced every year. At present, the yeast mud is mainly used as fertilizer matrix after dry compost, which reduces the added value it should have.

Pichia pastoris contains rich proteins, ribonucleic acid (RNA), polysaccharide and other nutrients. Extraction of these intracellular materials from yeast cells is significant for the maximum utilization of yeast resource. However, due to the thick cell wall and firm network structure composed of dextrin, mannose and protein (Cui-zhu Yang et al., 2006) [3], intracellular proteins extraction is faced with many restrictions. So far, yeast cell breaking methods have been reported in many literatures, such as ultrasonic method, hot acid treatment, biological enzymatic treatment (Yan Li et al., 2008; Ding-wei Cui et al, 2010; Su-qing Zhang and Gui-Lan Gao, 
2008) [4]-[6]. But there are still many drawbacks: ultrasonic method produces high temperature to make protein denaturation (Jun-hua Zeng et al., 2005) [7], enzyme hydrolysis method is costly and leads to the product inhibition (Bin Wang et al., 2013) [8]. In this study, suitable methods of cell wall breaking and extraction of intracellular proteins from Pichia pastoris were investigated.

\section{Materials and Methods}

\subsection{Experimental Materials}

Fresh pichia pastoris mud (provided from a fermentation corporation, Luoyang Henan). Yeast lyric enzyme (Pang Bo Biological Engineering Limited Company, Nanning Guangxi).

\subsection{Equipment}

NS1001L High pressure homogenizer (Italy Nrio GEA Company); Delta 320 Acidity meter (Mettle Toledo Company). TDL-5A Centrifuge (Shanghai Fichal Analysis Instrument Co., Ltd.); DK-S24 Thermostat water bath (Shanghai Jing Hong Experimental Equipment Co., Ltd.); SHA-B Thermostatic oscillator (Jintan science and Technology Instrument Co., Ltd.).

\subsection{Methods}

\subsubsection{Pichia pastoris Mud Pretreatment}

Fresh pichia pastoris mud was washed by distilled water (2 volumes of yeast mud) and centrifugated and precipitation was collected, then washed again by distilled water ( 1 volume of yeast mud) to remove the salt on the surface of Pichia Pastoris cells. Then distilled water was added to the Pichia pastoris cell mud to make the concentration of cell suspension 30\% (w/v) and the moisture content of the Pichia pastoris cells mud was determined.

\subsubsection{Biological Enzymatic Hydrolysis Treatment}

$500 \mathrm{~mL}$ Pichia pastoris cell suspension was equally divided into 5 parts, then $0.1 \%$, $0.2 \%$, $0.3 \%$, $0.4 \%$ and $0.5 \%$ o $(\mathrm{w} / \mathrm{v})$ of yeast lyric enzyme were added to the Pichia pastoris cell suspension respectively for 12 hours at $50^{\circ} \mathrm{C}$. After enzymatic hydrolysis, cell breaking efficiency was investigated; supernatant was collected and protein yield was measured.

\subsubsection{Alkali-Heating Treatment}

$500 \mathrm{~mL}$ Pichia pastoris cell suspension was equally divided into 5 parts, then adjusted $\mathrm{pH}$ to 7, 8, 9, 10, 11 respectively, water bath for 2 hours at $60^{\circ} \mathrm{C}$, stirred every $10 \mathrm{~min}$. After alkali-heating treatment, cell breaking efficiency was investigated; supernatant was collected and protein yield was determined.

\subsubsection{High-pressure homogenizing treatment}

Adjust $\mathrm{pH}$ of $1000 \mathrm{~mL}$ cell suspension of Pichia pastoris to 8.0, divided equally into 5 parts. Each part was carried out with high-pressure homogenizing, the homogenized pressure were $40 \mathrm{MPa}, 60 \mathrm{MPa}, 80 \mathrm{MPa}, 100$ $\mathrm{MPa}$ and $120 \mathrm{MPa}$, respectively. After homogenization treatment, cell breaking efficiency was investigated; supernatant was collected and protein yield was determined.

\subsubsection{Effect of Breaking Times on Protein Yield of Pichia pastoris Cells}

Distilled water, $50 \mathrm{mM}$ phosphate buffer ( $\mathrm{pH} 8.0$ ), $0.15 \mathrm{~mol} / \mathrm{L} \mathrm{NaCl}$ were used to make the concentration of $P i$ chia pastoris cell suspension $30 \%$. The homogenizing pressure was $80 \mathrm{MPa}$; the homogenizing number was 1 to 5 times respectively.

\subsubsection{Alkali-Heating and High-Pressure Homogenizing Treatment}

Adjusted $\mathrm{pH}$ of each $1000 \mathrm{~mL}$ Pichia pastoris suspension to 7.0 and 8.0 respectively, and then water bath for $2 \mathrm{~h}$ at $60^{\circ} \mathrm{C}$. After the bath, the two samples were equally divided into four parts, homogenized under $60 \mathrm{MPa}, 80$ MPa, $100 \mathrm{MPa}$ and $120 \mathrm{MPa}$ conditions respectively. After homogenization treatment, cell breaking efficiency 
was investigated; supernatant was collected and protein yield was measured.

\subsubsection{Effect of Cell Concentration on Protein Yield}

$50 \mathrm{mM}$ phosphate buffer (pH8.0) was used to make concentration of Pichia pastoris suspension $10 \%, 20 \%, 30 \%$, $40 \%$ and $50 \%$ (w/v, wet weight) with each volume of $200 \mathrm{ml}$. Water bath for 2 hours at $60^{\circ} \mathrm{C}$, homogenized twice under pressure of $100 \mathrm{MPa}$. After homogenization, supernatant was collected and protein yield was measured.

\subsubsection{Determination of Breaking Efficiency of Pichia pastoris Cells}

$1 \mathrm{~mL}$ of Pichia pastoris suspension before and after treatment was selected and observed using hemocytometer after dilution. The number of yeast with intact morphology was counted. Each sample was counted 5 times, and the average value was obtained. The number difference between intact cells before $\left(\mathrm{N}_{\mathrm{b}}\right)$ and after $\left(\mathrm{N}_{\mathrm{a}}\right)$ treatment was got, which was designated $\mathrm{N}_{\mathrm{b}-\mathrm{a}}$; cell breaking rate (\%) was the ratio of $\mathrm{N}_{\mathrm{b}-\mathrm{a}} / \mathrm{N}_{\mathrm{b}}$.

\subsubsection{Yield Determination of Released Protein}

The cell debris was removed after centrifugation, supernatant was collected and protein concentration was measured using Bradford method after dilution. The released protein yield was the ratio of proteins in supernatant and dry weight of Pichia pastoris mud.

\section{Results Discussions}

\subsection{Effect of Biological Enzymatic on Cell Wall-Breaking}

The results showed that with increased amount of wall breaking enzyme, the efficiency of cell breaking was higher (Figure 1). When the dosage of enzyme was between $0.1 \%$ - $0.4 \%$, the efficiency of cell breaking changed significantly, and yield of released protein also increased extremely. When the dosage of enzyme was more than $0.4 \%$, increased protein yield was not obvious. In conclusion, the effect of single biological enzymatic treatment on yeast cell wall-breaking was limited. The results indicated that maximum efficiency of cell breaking was about $20 \%$, and the released protein yield was also lower.

\subsection{Effect of Alkali-Heating on Cell Wall-Breaking}

Figure 2 showed that the low broken efficiency appeared when the $\mathrm{pH}$ was below 8.0 and with the increase of $\mathrm{pH}$ value, the cell breaking efficiency improved significantly. Cell breaking efficiency could reach $36.2 \%$ at $\mathrm{pH}$ 11.0. The change trend of protein release yield was consistent with cell breaking efficiency. Results indicated that extending the heat treatment time or increasing alkalinity could make the protein solution darker. This phenomenon might be due to protein denaturation caused by the reaction between breakage of disulfide bond of the released intracellular proteins and alkali.

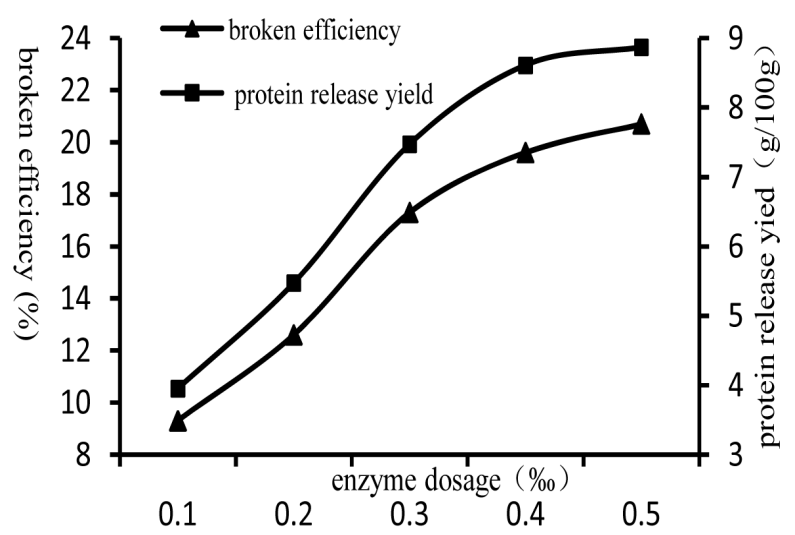

Figure 1. Effect of Biological enzymatic treatment on cell wallbreaking. 


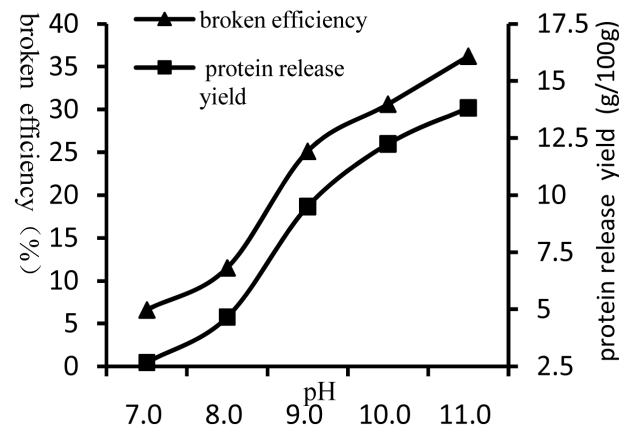

Figure 2. Effect of alkali-heating treatment on cell wall-breaking.

\subsection{Effect of High-Pressure Homogenizing Treatment on Cell Wall-Breaking}

The results of the high pressure-homogenizing treatment on cell wall-breaking indicated that when the homogenized pressure was less than $60 \mathrm{MPa}$, the cell breaking efficiency was low. When the pressure increased to 100 $\mathrm{MPa}$, the efficiency of yeast cell breaking changed significantly, and protein release yield also increased accordingly (Figure 3). The results indicated that appropriate homogeneous condition should be considered in the process of production, because higher pressure could lead to damage of equipment, which was easily to increase production costs.

\subsection{Effect of Homogenized Times and Suspension Medium on Cell Wall-Breaking}

Homogenizing times had a great influence on the efficiency of yeast cell breaking in suspension. Results showed that, more than $90 \%$ of the yeast cells could be broken after 3 times of homogenization, the intracellular protein release yield also increased accordingly (Table 1). The breaking efficiency and protein release yield were not significantly improved when homogenized time were more than 3 . The results indicated that higher broken efficiency and protein release yield were obtained when using $50 \mathrm{mM}$ phosphate buffer $(\mathrm{pH} 8.0)$ and $0.15 \mathrm{M} \mathrm{NaCl}$ as suspended medium than that of distilled water.

\subsection{Effect of Alkali-Heating and High-Pressure Homogenizing on Cell Wall-Breaking}

The effect on the yeast cell breaking efficiency and protein yield of two conditions of $\mathrm{pH} 9.0$ and $\mathrm{pH} 10.0$ were studied and compared under condition of water bath for 2 hours at $60^{\circ} \mathrm{C}$ and $100 \mathrm{MPa}$ pressure homogenized twice. Table 2 indicated that with increasing of homogenization pressure, the efficiency of cell breaking and the protein yield increased at $\mathrm{pH} 9.0$ and $\mathrm{pH}$ 10.0. The efficiency of yeast cell breaking can reach $87.6 \%$ when homogenized twice at $\mathrm{pH}$ 10.0; both efficiency of cell breaking and protein yield were higher than that of $\mathrm{pH} 9.0$.

\subsection{Effect of Cell Concentration on the Extraction of Intracellular Proteins}

Cell concentration on the extraction of intracellular proteins was also investigated. The results indicated that protein release yield decreased with the increasing of cell concentration (Figure 4). The cell concentration was less than $30 \%$, the protein release yield decreased extremely while the downtrend slowed down when the concentration was higher than $30 \%$. In conclusion, low concentration of cells led to higher broken efficiency, however, the protein yield was less, and the production cost of protein extraction was higher compared with that of high density cells. Appropriate cell concentration was favorable for the subsequent production.

\section{Discussion}

In recent years, different methods of yeast cell wall breaking have been developed, but each method has its own limitations (Cui-zhu Yang et al., 2006) [3]. Previous studies pay more attention to obtaining higher cell breaking efficiency and more products. Quality of the products and industrial production costs are ignored. Chen (2014) [9] and other researchers found that using high pressure cell breaking apparatus could reach the highest efficiency. 


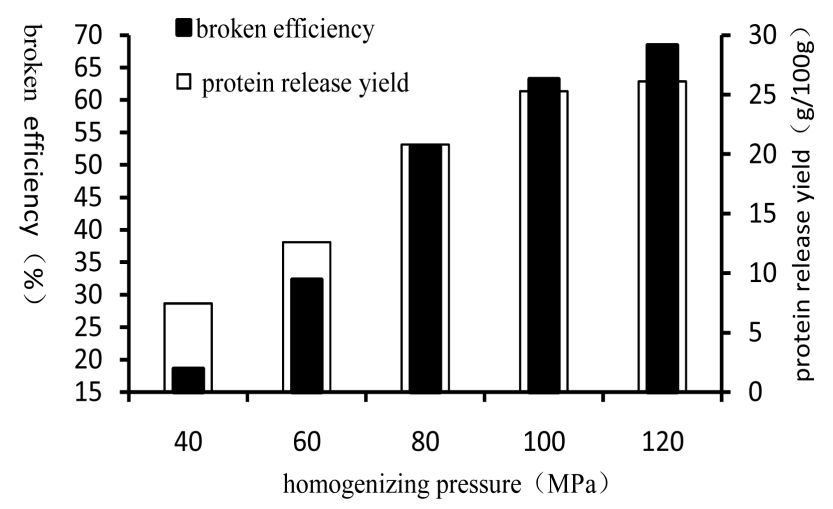

Figure 3. Effect of high-pressure homogenizing treatment on cell wall-breaking.

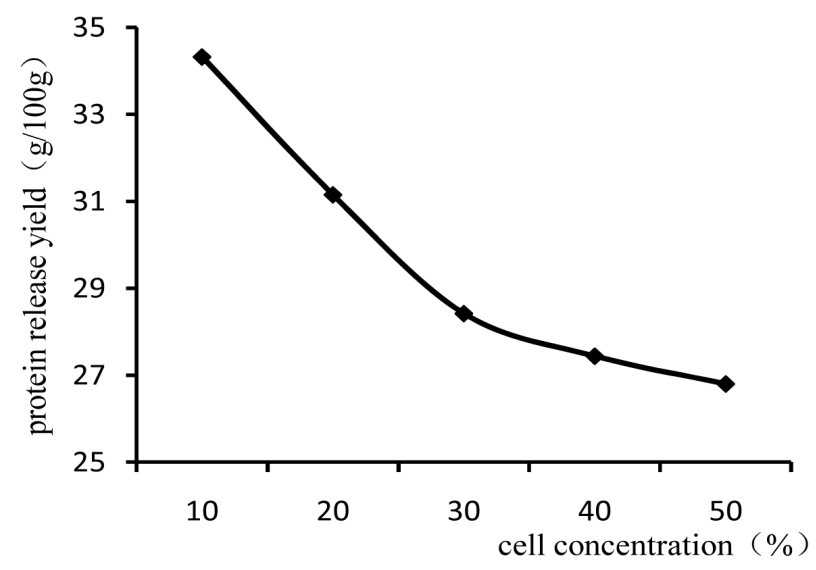

Figure 4. Effect of cell concentration on the extraction of intracellular protein.

Table 1. Effect of homogenized times and suspension medium on cell wall-breaking.

\begin{tabular}{ccccccc}
\hline & \multicolumn{3}{c}{ Broken efficiency (\%) } & \multicolumn{3}{c}{ Protein release yield (g/100g) } \\
\cline { 2 - 7 } Homogenizing times & $\begin{array}{c}\text { Distilled } \\
\text { water }\end{array}$ & $\begin{array}{c}\text { Phosphate } \\
\text { buffer solution }\end{array}$ & $\begin{array}{c}\text { NaCL } \\
\text { solution }\end{array}$ & $\begin{array}{c}\text { Distilled } \\
\text { water }\end{array}$ & $\begin{array}{c}\text { Phosphate } \\
\text { buffer solution }\end{array}$ & $\begin{array}{c}\text { NaCL } \\
\text { solution }\end{array}$ \\
\hline 1 & 53.2 & 60.3 & 58.1 & 20.75 & 24.55 & 22.62 \\
2 & 76.6 & 78.5 & 78.8 & 30.07 & 35.40 & 31.13 \\
3 & 90.1 & 92.5 & 90.9 & 35.21 & 37.46 & 36.36 \\
4 & 91.2 & 93.6 & 92.8 & 36.02 & 37.90 & 37.03 \\
5 & 92.5 & 94.1 & 92.6 & 36.90 & 37.64 & 36.88 \\
\hline
\end{tabular}

Table 2. Effect of alkali-heating and high-pressure homogenizing on cell wall-breaking.

\begin{tabular}{clccc}
\hline \multirow{2}{*}{$\begin{array}{c}\text { Homogenizing pressure } \\
\text { (MPa) }\end{array}$} & \multicolumn{2}{c}{ Broken efficiency (\%) } & \multicolumn{2}{c}{ Protein release yield (g/100g) } \\
\cline { 2 - 5 } & $\mathrm{pH} \mathrm{9.0}$ & $\mathrm{pH} \mathrm{10.0}$ & $\mathrm{pH} \mathrm{9.0}$ & $\mathrm{pH} \mathrm{10.0}$ \\
\hline 60 & 51.1 & 65.5 & 19.80 & 26.20 \\
80 & 69.4 & 79.1 & 27.41 & 32.29 \\
100 & 78.3 & 87.6 & 30.77 & 35.48 \\
120 & 86.6 & 89.1 & 35.07 & 35.64 \\
\hline
\end{tabular}


After breaking for 10 times, the protein release yield and protein activity were the highest. The scale production of this method could increase the cost of production; it was suitable for the extraction of the high value material from cells. Wu (2007) [10] combined high-pressure homogenizing, enzymatic dissolution and temperature variations to study yeast extraction, the efficiency of protein release could reached $86.5 \%$. In this study, we combined enzymatic treatment and high-pressure homogenizing to broke the cell walls, however, the effect was not obvious due to the thickening in the late fermentation stage of Pichia pastoris. Li (2008) found that alkali could lyse yeast cell modestly and broken efficiency was better compared with salt method in the study of nucleic acid extraction. In this study, combination of alkali-heating and high-pressure homogenizing could lead to higher cell broken efficiency compared with enzymatic, alkali-heating and high-pressure homogenizing respectively. In this paper, in consideration of production cost, use and properties of the extracted proteins, the optimal conditions of the alkali-heating and high-pressure homogenizing method was that $\mathrm{pH} 10.0$, water bath for 2 hours at $60^{\circ} \mathrm{C}, 100$ $\mathrm{MPa}$ pressure homogenized twice, under this condition the ideal efficiency of yeast cell breaking could reach $87.6 \%$.

\section{Acknowledgements}

The authors would like to acknowledge the funding from the support program of science and technology innovation team in colleges and universities of Henan province (15IRTSTHN019).

\section{References}

[1] Dai, J.-L., Li, Y. and Ma, Q. (2012) Optimization of Ultrasonic Treatment for Recovery of Recombinant Protein from Pichia pastoris. Food Science, 33, 57-60.

[2] Lou, R.-J., Luo, L.-L. and Zhang, X. (2010) Research Progress and Prospects on Pichia pastoris. Journal of Biology, 27, 73-76.

[3] Yang, C.-Z., Li, Y., Ruan, N., et al. (2006) Study and Applications of Technology about Breaking Yeast Cell Wall. Food Science and Technology, 7, 138-142.

[4] Li, Y., Ruan, N., Yang, C.-Z., et al. (2008) Effects of Different Methods of breaking Cells Wall on Yeast RNA Extraction. Food Science, 29, 204-206.

[5] Cui, D.-W., Hu, X.-C., Bao, S.-S. and Zhang, K. (2010) Research Progress in Enzymatic Disruption of Microbial Cells. Institute of Microbiology, 37, 1672-1678.

[6] Zhang, S.-Q. and Kao, G.-L. (2008) The Study of the Effect for the Shiver of the Yeast Cell Using Acid-Heat Shiver. Journal of Inner Mongolia Agricultural University, 29, 15-18.

[7] Zeng, J.-H., Wang, C.-L. and Zhang, M. (2005) Study on Releasing S-Adenosyl-L-M Ethionine by Breaking Yeast Cells. Amino Acids\& Biotic Resources, 27, 49-51.

[8] Wang, B., Huang, L.-N. and Qiu, L.-J. (2013) Study on Moderate Wall-Breaking Preparation Lipoprotein of Yeast Source. China Biotechnology, 33, 92-96.

[9] Chen, T.-J. and Zhu, P. (2014) The Effect of High-Pressure Homogenized Engineered Yeast Cells, Low Temperature Preservation and De Glycosylation Treatment on the Activity of LXYL-P1-2. Chinese Medical Biotechnology, 9, 381-384.

[10] Wu, R.-J., Liu, Z.-Y. and Zhang, X.-T. (2007) Extraction of Yeast Monosodium Glutamate from Waste Beer Yeast by the Synthetic Technique of Breaking and Dissolving Cell Wall. Liquor-Making Science \& Technology, 11, 95-96. 